\title{
HIGH SPEED FRICTION WELDING OF TITANIUM ALLOYS - STRUCTURE AND PROPERTIES OF JOINTS*
}

\author{
D. MIARA ${ }^{1}$, J. MATUSIAK ${ }^{1}$, A. PIETRAS ${ }^{1}$, M. KRYSTIAN ${ }^{2}$, M. DYNER ${ }^{3}$ \\ ${ }^{1}$ Institute of welding. 44-100, Gliwice, Str. Bl. Czeslava 16-18, Poland. E-mail: adam.pietras@is.gliwice.pl \\ ${ }^{2}$ Austrian Institute of Technology, Str. Giefinggasse 4, 1210, Vienna, Austria. E-mail: marciej.krystian@univil.ac.at \\ ${ }^{3}$ Plant of Medical Instruments CHIRMED, Str.. Mstowska 8A, 42-240 Rudniki, Czestochowy, Poland. \\ E-mail: m.dyner@chirmed.pl
}

\begin{abstract}
The article presents test results concerning the high speed friction welding (HSFW) of titanium alloys Ti64 ELI and CP-Ti. In addition, the article presents tests results related to the welding process and the formation of flash. The quality of welds was assessed on the basis of non-destructive tests (visual tests) and destructive tests (static tensile tests and bend tests). The tests resulted in the identification of the correlation between HSFW conditions when joining titanium alloys, i.e. Ti64 ELI, CP-Ti, and the quality of welds. Consequently, the tests led to the determination of the optimum range of welding parameters as regards the strength of joints. 8 Ref., 2 Tabl., 6 Fig.
\end{abstract}

Keywords: friction welding, titanium alloys, structure and properties

\section{Introduction}

Conventional friction welding (FW) and high speed friction welding (HSFW) are solid-state joining processes and belong to few processes utilising friction heat emitted during the technological process [1-3].

Most metals (including titanium alloys) are joined using friction welding, where the kinetic energy of the relative motion of elements subjected to welding is transformed into friction heat. There are many various manners in which surfaces to be joined move in relation to each other, where the simplest and most commonly used in industrial practice is rotational motion.

During welding, elements heated by friction heat are pressed against each other by friction downward force, which leads to the movement of metal in the welding area outside the frictionplasticised contact to the so-called metal flash $[3,4]$. After the appropriate heating and plasticisation of the material in the welding area the relative motion of elements stops. The joint is obtained after the complete stoppage of motion and the exertion of additional upsetting force so that the contact surfaces of elements could reach the distance of atomic force action. The welding process leads to the formation of a compact structure across the entire cross-section of elements being joined. During friction and upsetting the elements being welded become shorter $[3,4]$. Conventional friction welding is usually performed at

\footnotetext{
* По материалам доклада, представленного на международной конференции «Титан 2018. Производство и применение в Украине», 11-13 июня 2018, Киев, ИЭС им. Е. О. Патона.
}

rotation rates restricted within the range of $500 \mathrm{rpm}$ to $5000 \mathrm{rpm}$ [5].

High speed friction welding (HSFW) is a variety of conventional friction welding (FW), where the process of welding is preformed using rotation rates reaching approximately $25000 \mathrm{rpm}$ [6]. The use of the above-named high rotation rates significantly changes joining conditions in comparison with the conventional method of friction welding. The foregoing can be observed when analysing the correlation between the element shortening rate and the rate of friction as well as the change in the thickness of a layer subjected to plastic strain and the change in the friction rate. Because of significantly varying weld formation mechanisms during the HSFW process it is possible to considerably reduce the time of welding (to several seconds) and decrease diameters of elements being welded (to a mere $5 \mathrm{~mm}$ ).

Both during the conventional and the high speed friction welding process attention is drawn primarily to the identification of the appropriate range of welding parameters, particularly to the correlation between the rotation rate of the spindle and the downward force. The foregoing is particularly important when adjusting optimum welding parameters in relation to individual materials as it affects the joint formation mechanism and joint properties.

\section{Test stand}

The welding process was performed using an RSM400 HSFW station (Fig. 1, $a$ ) and bars having a diameter of $10 \mathrm{~mm}$ and made of titanium alloys Ti64 ELI and CP-Ti. The chemical composition and selected physical properties of materials in the as-delivered state used in the tests are presented in 


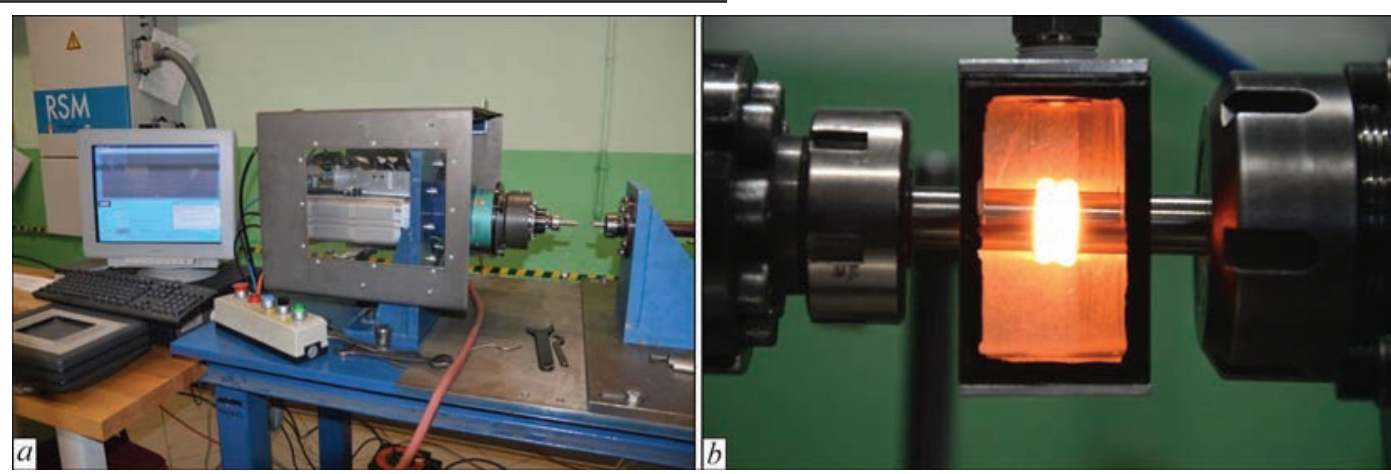

Fig 1. RSM400 HSFW machine: $a$ — welding station with the measurement system; $b$ - welding of titanium Ti64 ELI [1]

Ta b l e I. Chemical composition of the titanium alloys used in the tests

\begin{tabular}{|c|c|c|c|c|c|c|c|c|c|}
\hline \multirow{2}{*}{ No. } & \multirow{2}{*}{ Alloy designation } & \multicolumn{8}{|c|}{ Chemical element content, $\%$} \\
\hline & & $\mathrm{Al}$ & $\mathrm{V}$ & $\mathrm{O}$ & $\mathrm{Fe}$ & $\mathrm{C}$ & $\mathrm{N}$ & $\mathrm{H}$ & $\mathrm{Ti}$ \\
\hline 1 & Ti64 ELI (Ti6Al-4V) & 5.930 & 3.960 & 0.103 & 0.180 & 0.023 & 0.002 & - & rest \\
\hline 2 & $\mathrm{CP}-\mathrm{Ti}$ & - & - & 0.210 & 0.220 & 0.010 & 0.040 & 0.001 & rest \\
\hline
\end{tabular}

Ta b I e I I. Selected properties of the titanium alloys used in the tests

\begin{tabular}{||c|c|c|c|c|}
\hline \multirow{2}{*}{ No. } & \multirow{2}{*}{ Alloy designation } & \multicolumn{3}{|c|}{ Minimum properties } \\
\cline { 3 - 5 } & & $R_{\mathrm{p} 0,2}, \mathrm{MPa}$ & $R_{\mathrm{m}}, \mathrm{MPa}$ & $A_{50 \mathrm{~mm}}, \%$ \\
\hline 1 & Ti64 ELI (Ti6Al-4V) & 795 & 860 & 10 \\
\hline 2 & CP-Ti & 610 & 520 & 22 \\
\hline
\end{tabular}

Tables I and II. The materials were welded in the similar material joining configuration. The welding station was provided with an additional housing preventing the access of oxygen to the argon-shielded process. The welding process and the housing with the shielding gas are presented in Fig. $1, b$.

The tests of the HSFW of titanium alloys Ti64 ELI and CP-Ti were performed using the following welding parameters:

a) during the welding of titanium alloy Ti64 ELI: rotation rate $V_{\mathrm{n}}=20000 \mathrm{rpm}$, friction time $t_{\mathrm{t}}=0.5 \mathrm{~s}$, friction downward force $f_{\mathrm{t}}=3$ bar, upsetting time $t_{\mathrm{s}}=$ $=3 \mathrm{~s}$ and upsetting force $f_{\mathrm{s}}=6 \mathrm{bar}$.

b) during the welding of titanium alloy CP-Ti: rotation rate $V_{\mathrm{n}}=20000 \mathrm{rpm}$, friction time $t_{\mathrm{t}}=0.5 \mathrm{~s}$, friction downward force $f_{\mathrm{t}}=1 \mathrm{bar}$, upsetting time $t_{\mathrm{s}}=$ $=3 \mathrm{~s}$ and upsetting force $f_{\mathrm{s}}=3$ bar.

\section{Visual tests}

Selected welds of titanium alloys Ti64 ELI and CP-Ti made using the HSFW process are presented in Fig. 2. The obtained friction welds were characterised by the specific shape of flash, the size of which varied in relation to the material subjected to welding. The flash formed during the welding of titanium alloy $\mathrm{CP}$ -

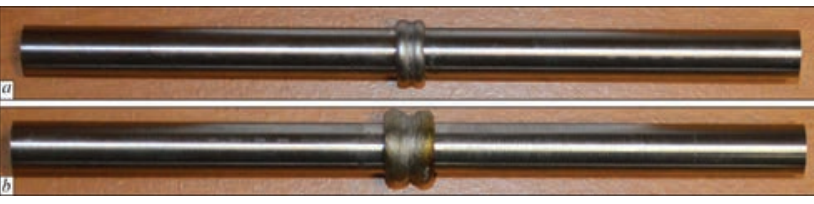

Fig. 2. Welds in titanium alloys Ti64 ELI ( $a$ ) and CP-Ti (b) made using the HSFW process [1]
Ti was significantly larger than that formed during the welding of titanium alloy Ti64 ELI.

\section{Macroscopic metallographic tests}

All of the test welds were subjected to macroscopic metallographic tests. The test specimens were cut out mechanically and subjected to grinding and polishing until the obtainment of appropriate smoothness. The metallographic tests were performed in accordance with the requirements of the PNEN ISO 17639:2013-12 standard [7]. The structure of related metallographic specimens was revealed using the Keller's reagent. Macrostructures of selected welds made of titanium alloys Ti64 ELI and CP-Ti using the HSFW process are presented in Fig. 3, $a$ and 3, $b$ respectively. The macroscopic metallographic test results revealed that the structure of the welds was proper and characteristic of the friction welding method. The size and shape of flashes depended on a material subjected to welding

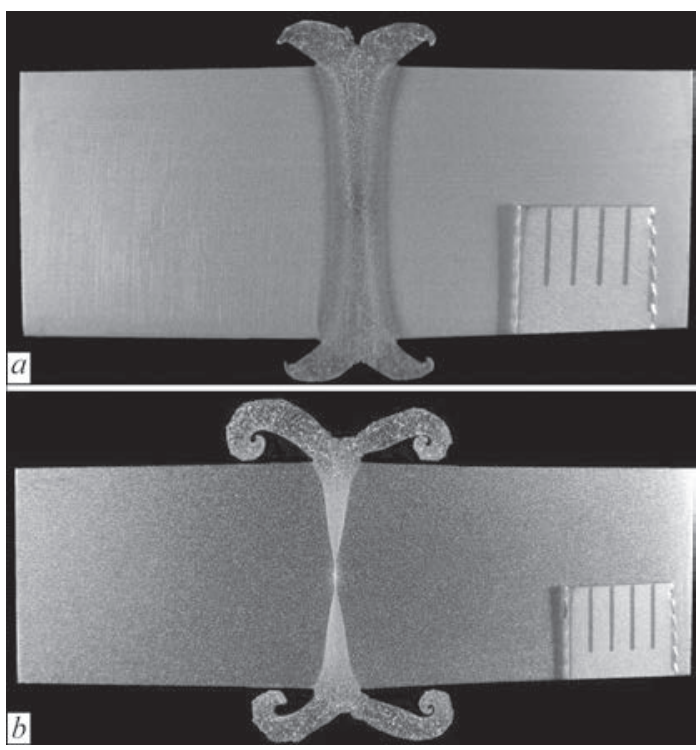

Fig. 3. Macrostructures of the welds in titanium alloys Ti64 ELI (a) and CP-Ti (b) made using the HSFW process [1] 
and applied welding process parameters. The materials subjected to welding revealed various HAZ areas and the distribution of individual zones in the welding area.

\section{Tensile tests}

The mechanical properties of the welds made using the HSFW process were identified in a static tensile test performed in accordance with the requirements of PN-EN ISO 4136:2013-05E [8]. The joints were subjected to uniaxial tension performed using an INSTORN 4210 testing machine. The tests were performed at ambient temperature and a strain rate of $5 \mathrm{~mm} / \mathrm{min}$. The test results concerning the strength of the friction welds made of titanium alloys Ti64 ELI and CP-Ti using the HSFW process are presented in Fig. 4.

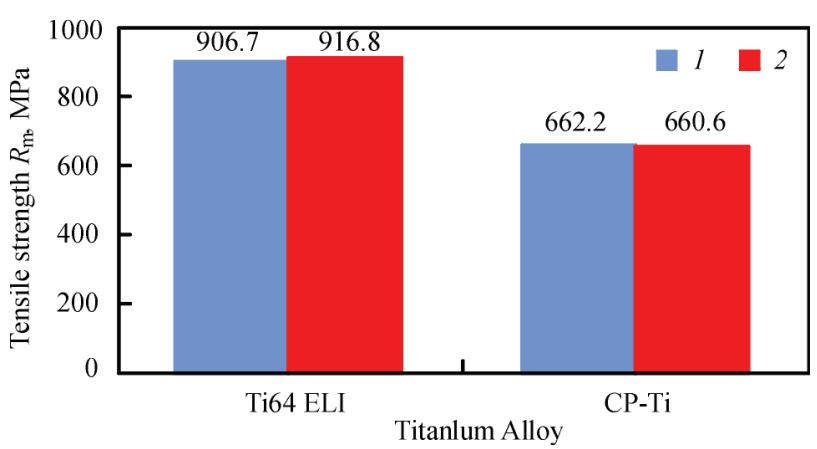

Fig. 4. Tensile strength of titanium alloy Ti64 ELI and CP-Ti [1]: 1 - parent materials, 2 - welded materials

The test results are presented in relation to the base material of alloy Ti64 ELI and that of CP-Ti. As regards titanium alloy Ti64 ELI, the mean strength of the base material amounted to $906.7 \mathrm{MPa}$, whereas the mean strength of the friction welds amounted to 916.8 $\mathrm{MPa}$, i.e. was on average by $1.1 \%$ higher than that of the base material. The materials in the welding area were hardened during the welding process. As regards titanium alloy CP-Ti, the mean hardness of the base material amounted to $662.2 \mathrm{MPa}$, whereas the mean value of friction welds (HSFW) amounted to 660.6 $\mathrm{MPa}$, i.e. was by a mere $0.3 \%$ lower than that of the base material. The above-presented high mean tensile strength values revealed that the welds made using the HSFW process were characterised by high and repeatable quality. The weld after being subjected to the tensile test is presented in Fig. 5.

\section{Bend tests}

Selected friction welds were also subjected to bend tests. The bend tests of all three test specimens made of titanium alloy Ti64 ELI proved successful, i.e. the specimens reached an assumed bend angle of $180^{\circ}$. In

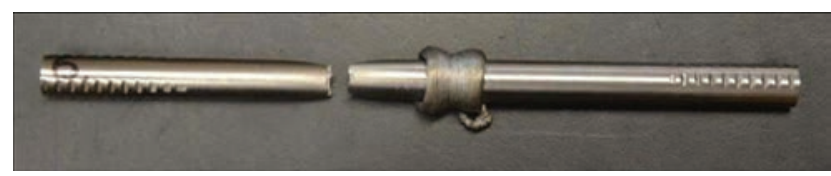

Fig. 5. Test specimen made of titanium alloy Ti64 after the tensile test [1] terms of the specimens made of titanium alloy CP-Ti, the assumed angle amounting to $180^{\circ}$ was reached by two out of three specimens. One specimen made of CPTi reached a bend angle of $50^{\circ}$ and developed a brittle crack in the base material, indicating the high quality of the welded joint. An example of the weld after the bend test is presented in Figure 6.

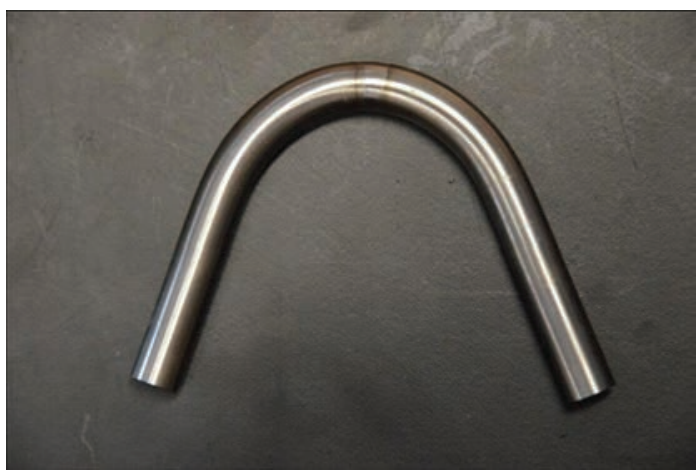

Fig. 6. Test specimen made of titanium alloy Ti64 after the bend test [1]

\section{Conclusions}

The above-presented tests and analyses of test results justified the formulation of the following conclusions:

Titanium alloys Ti64 ELI and CP-Ti can be welded using the high speed friction welding (HSFW) method. Appropriately adjusted welding conditions enable the obtainment of high-quality joints characterised by required mechanical properties.

Appropriately adjusted welding process parameters ensure process stability and joint repeatability.

The internal structure of both materials subjected to welding (titanium alloy Ti64 ELI and CP-Ti) was continuous and did not reveal the presence of «nojoint» traces or the lack of joint integrity (tightness).

The friction welding process performed using a special welding programme makes it possible to properly heat fragments of internal surfaces of titanium bars and, after exerting appropriate force, to obtain a joint characterised by required tensile and bend strength.

\section{References}

1. (2016) Project Anti-bacterial optimization of high-strength, severe-plastic-deformed titanium alloys for spinal implants and surgical tools - SPD-BioTribo) www.M-ERA. NET/2015/02/2016 (2016-09-2018-08-31) report no. 2.

2. Zadroga, L., Pietras, A., Papkala, H. (2004) Studium $i$ badania warunków taczenia materiałów różnoimiennych nowoczesnymi metodami zgrzewania tarciowego. Report of Research Instytutu Spawalnictwa, Gliwice.

3. Klimpel, A. (1999) Technologie zgrzewania metali i tworzyw termoplastycznych. Wydawnictwo Politechniki Śląskiej, Gliwice.

4. Michalski, R., Kamiński, Z. (1975) Zgrzewanie tarciowe. WNT, Warszawa.

5. Michalski, R. (1980) Typizacja procesu zgrzewania tarciowego. Praca badawcza nr T-17, Instytut Spawalnictwa, Gliwice.

6. Materials of HARMS \& WENDE. 
7. (2013) PN-EN ISO 17639:2013-12: Badania niszczace spawanych złaczy metali - Badania makroskopowe $i$ mikroskopowe złaczy spawanych.
8. (2013) PN-EN ISO 4136:2013-05E: Badania niszczace złaczy spawanych metali - Próba rozciagania próbek poprzecznych.

\title{
ВЫСОКОСКОРОСТНАЯ РОТАЦИОННАЯ СВАРКА ТИТАНОВЫХ СПЛАВОВ - СТРУКТУРА И СВОЙСТВА СОЕДИНЕНИЙ
}

\section{Д. МИАРА ${ }^{1}$, Дж. МАТУСЯК ${ }^{1}$, А. ПЬЕТРАС ${ }^{1}$, М. КРИСТИАН ${ }^{2}$, М. ДУНЕР}

${ }^{1}$ Институт сварки. 44-100 Гливице, ул. Бл. Чеслава 16-18, Польша. E-mail: adam.pietras@is.gliwice.pl ${ }^{2}$ Австрийский технологический институт, ул. Гифингассэ 4, 1210, Вена, Австрия. E-mail: marciej.krystian@univil.ac.at ЗЗавод медицинских инструментов CHIRMED, ул. Мстовска 8A, 42-240 Рудники, Ченстохов, Польша E-mail: m.dyner@chirmed.pl

В статье представлены результаты испытаний высокоскоростной ротационной сварки титановых сплавов Ti64 ELI и CР-Ті, используемых, среди прочего, при изготовлении хирургических инструментов. Кроме того, в статье представлены результаты испытаний, связанные с процессом сварки и образованием стыка. Качество сварных швов оценивали на основе неразрушающего контроля и механических испытаний (статические испытания на растяжение и испытания на изгиб). Испытания привели к идентификации корреляции между условиями высокоскоростной ротационной сварки при соединении титановых сплавов, т. е. Ti64 ELI и CP-Тi, и качества сварных швов. Получены оптимальные диапазоны параметров процесса сварки, обеспечивающие более высокие показатели прочности соединений. Библиогр. 8 , табл. 2 , рис. 6.

Ключев ве е слова: высокоскоростная ротационная сварка, титановые сплавы, структура и свойства

\section{ВИСОКОШВИДКІСНЕ РОТАЦІЙНЕ ЗВАРЮВАННЯ ТИТАНОВИХ СПЛАВІВ — СТРУКТУРА ТА ВЛАСТИВОСТІ З’ЄДНАНЬ}

\author{
Д. МІАРА ${ }^{1}$, Й. МАТУСЯК ${ }^{1}$, А. П'ЄТРАС ${ }^{1}$, М. КРИСТІАН ${ }^{2}$, М. ДУНЕР ${ }^{3}$ \\ ${ }_{1}^{1}$ Інститут зварювання. 44-100 Глівіце, вул. Бл. Чеслава 16-18, Польща. E-mail: adam.pietras@is.gliwice.pl \\ ${ }^{2}$ Австрійскій технологічний інститут, вул. Гіфінгассе 4, 1210, Відень, Австрія. E-mail: marciej.krystian@univil.ac.at \\ ЗЗавод медичних інструментів CHIRMED, вул. Мстовська 8A, 42-240 Рудники, Ченстохов, Польща \\ E-mail: m.dyner@chirmed.pl
}

\begin{abstract}
У статті представлені результати випробувань високошвидкісного ротаційного зварювання титанових сплавів Ti64 ELI і СР-Ті, використовуваних, серед іншого, при виготовленні хірургічних інструментів. Крім того, в статті представлені результати випробувань, пов'язані з процесом зварювання і утворенням стику. Якість зварних швів оцінювали на основі неруйнівного контролю та механічних випробувань (статичні випробування на розтягнення і випробування на вигин). Випробування привели до ідентифікації кореляції між умовами високошвидкісного ротаційного зварювання при з'єднанні титанових сплавів, тобто Ti64 ELI та CP-Ti, і якості зварних швів. Отримано оптимальні діапазони параметрів процесу зварювання, що забезпечують більш високі показники міцності з’єднань. Бібліогр. 8, табл. 2, рис. 6.
\end{abstract}

Ключов і слова: високошвидкісне ротаційне зварювання, титанові сплави, структура і властивості

\section{9 Международная конференция «ЛУЧЕВЫЕ ТЕХНОЛОГИИ И ПРИМЕНЕНИЕ ЛАЗЕРОВ»}

17-19 сентября 2018 г.

г. Санкт-Петербург (г. Пушкин)

Тематика конференции

Физические основы и математическое моделирование лучевых технологий. CAD-CAM-CAE системы.

- Оборудование и технологии сварки, наплавки и термообработки.

- Оборудование и технологии аддитивного производства.

- Оборудование и технологии резки, прошивки отверстий и обработки поверхности.

- Метрология, системы измерений и дефектоскопия.

Официальные языки конференции: английский, русский

www.ilwt-stu.ru 